\title{
Effect of long storage and soil type on the actual denitrification and denitrification capacity to $\mathrm{N}_{2} \mathrm{O}$ formation
}

\author{
Teresa Włodarczyk ${ }^{1}$, Pawet Szarlip ${ }^{1}$, Wojciech Koziet ${ }^{1}$, Magdalena Nosalewicz ${ }^{1}$, Małgorzata Brzezińska ${ }^{1}$, \\ Marek Pazur ${ }^{1}$, and Emilia Urbanek ${ }^{2}$ \\ ${ }^{1}$ Institute of Agrophysics, Polish Academy of Sciences, Doświadczalna 4, 20-290 Lublin, Poland \\ ${ }^{2}$ Department of Geography, Swansea University, Swansea SA2 0NA, UK
}

Received February 18, 2013; accepted January 23, 2014

\begin{abstract}
A b s t r a c t. The actual denitrification to $\mathrm{N}_{2} \mathrm{O}$ and denitrification capacity to $\mathrm{N}_{2} \mathrm{O}$ after flooding of different soil samples stored for over 25 years in air-dry conditions and fresh, air dried samples were compared in our study. Zero $\mathrm{N}_{2} \mathrm{O}$ release was observed from the stored soils but the fresh soil samples had very low actual denitrification to $\mathrm{N}_{2} \mathrm{O} \cdot \mathrm{NO}_{3}{ }^{-}$addition significantly increased the amount of $\mathrm{N}_{2} \mathrm{O}$ (denitrification capacity to $\mathrm{N}_{2} \mathrm{O}$ ) released after flooding, which depended on the length of storage and type of soils and was much higher in stored soils. Prolonged exposure of the soils to drought conditions caused a greater decrease in the Eh value compared with the fresh soil. The total cumulative release of $\mathrm{N}_{2} \mathrm{O}$ from the stored and fresh soils was correlated with the reduced $\mathrm{NO}_{3}{ }^{-}$and organic $\mathrm{C}$ content in soils enriched with $\mathrm{NO}_{3}{ }_{3}^{-}$. Some soils showed the capability of $\mathrm{N}_{2} \mathrm{O}$ consumption. $\mathrm{CO}_{2}$ release depended on the length of storage and type of soils under flooding after prolonged drought. On average, $\mathrm{CO}_{2}$ release was higher from the stored rather than fresh soils. The organic $\mathrm{C}$ content in the stored soils was generally lower than in the fresh soils, probably due to the storage effect. The cumulative $\mathrm{CO}_{2}$ release from the stored soils was well correlated with the organic $\mathrm{C}$ while no correlation was observed for the fresh soil samples.

$\mathrm{K}$ e y w o r d s: actual denitrification to $\mathrm{N}_{2} \mathrm{O}$, denitrification capacity to $\mathrm{N}_{2} \mathrm{O}$, long- and very short-storage time, soil respiration, archived soil
\end{abstract}

\section{INTRODUCTION}

Biological activity in soil can be represented by several different parameters such as respiration, enzyme activity, ammonification, nitrification, denitrification, and emission of gaseous metabolites as well as oxidation-reduction processes (Bieganowski et al., 2013; Włodarczyk et al., 2011).

*Corresponding author e-mail: t.wlodarczyk@ipan.lublin.pl **The paper was financed by the Ministry of Science in Poland, project No. NN 310115338, 2010-2013 .
Soils are subjected to temporal variations in temperature and moisture that can cause changes in physicochemical properties. Soil dry/wet cycles result from natural variations in soil moisture driven by environmental and biophysical processes such as precipitation, evapotranspiration, and drainage. Management factors such as irrigation, tillage and land cover (ie. vegetation type) can moderate or accentuate the amplitude of these natural cycles (Oliveira et al., 2005).

Under in situ conditions, denitrification rates depend on oxygen availability, soil moisture, soil type, $\mathrm{pH}, \mathrm{NO}_{3}{ }^{-}$concentration, but also on the availability of labile carbon compounds in soil (Burford and Bremner, 1975; Senbayram et al., 2009).

Nitrate $\left(\mathrm{NO}_{3}{ }^{-}\right)$is a key node in the network of the assimilatory and respiratory nitrogen pathways. For bacteria, it is both a nitrogen source and an electron acceptor (Hayatsu et al., 2008). In agriculture and wastewater treatment, $\mathrm{NO}_{3}{ }^{-}$ respiration by microorganisms is an important process in respect to economics, greenhouse gas emission, and public health. Several microbial processes compete for $\mathrm{NO}_{3}{ }^{-}$: denitrification, dissimilatory $\mathrm{NO}_{3}{ }^{-}$reduction to ammonium $\left(\mathrm{NH}_{4}{ }^{+}\right)$, and anaerobic ammonium oxidation. Denitrification is a respiratory process in which $\mathrm{NO}_{3}{ }^{-}$is reduced stepwise to dinitrogen $\left(\mathrm{N}_{2}\right)\left(\mathrm{NO}_{3}{ }^{-} \rightarrow \mathrm{NO}_{2}{ }^{-} \rightarrow \mathrm{NO} \rightarrow \mathrm{N}_{2} \mathrm{O} \rightarrow \mathrm{N}_{2}\right)$. In bacteria, this process is used as an alternative to oxygen $\left(\mathrm{O}_{2}\right)$ respiration under low $\mathrm{O}_{2}$ or under anoxic conditions (Włodarczyk et al., 2005).

Intense agricultural fertilization may lead to increased concentrations of $\mathrm{NO}_{3}{ }^{-}$in the groundwater (Almasri and Kaluarachchi, 2004). Furthermore, fertilization increases the atmospheric concentrations of methane and nitrous 
oxide $\left(\mathrm{N}_{2} \mathrm{O}\right)$ and thus contributes to greenhouse gas emissions and global warming (Hanke and Strous, 2010). As a potent greenhouse gas, $\mathrm{N}_{2} \mathrm{O}$ is responsible for about $6 \%$ of the current greenhouse effect (IPCC, 2007). Moreover, $\mathrm{N}_{2} \mathrm{O}$ has received great attention because of its importance for stratospheric ozone depletion (Ravishankara et al., 2009). Globally, agricultural soils account for about $60 \%$ of the atmospheric $\mathrm{N}_{2} \mathrm{O}$ emissions (Kroze et al., 1999).

Soil organic matter (SOM) content and texture are important factors affecting carbon $(\mathrm{C})$ and nitrogen $(\mathrm{N})$ mineralization under constant soil moisture but their effects on organic matter mineralization and associated biogenic gas $\left(\mathrm{CO}_{2}\right.$ and $\left.\mathrm{N}_{2} \mathrm{O}\right)$ production during dry/wet cycles is poorly understood (Harrison-Kirk et al., 2013). Kraft et al. (2011) showed that knowledge of the mechanism of $\mathrm{NO}_{3}{ }^{-}$reduction in natural ecosystems is still not clear. Although a fair number of studies on pure cultures have been performed, little is known about how the natural microbial communities of terrestrial and aqueous habitats react to changing $\mathrm{NO}_{3}{ }^{-}$ concentrations and nitrogen speciation.

Easily available soil organic carbon and type of soil are important factors affecting $\mathrm{NO}_{3}{ }^{-}$respiration and $\mathrm{C}$ mineralization but their effects on $\mathrm{CO}_{2}$ and $\mathrm{N}_{2} \mathrm{O}$ production during flooding of dry soil is rarely investigated and poorly understood (Włodarczyk et al., 2005).

Very important information from the point of view of agricultural practices (loss of $\mathrm{N}$ ) and the environmental protection $\left(\mathrm{N}_{2} \mathrm{O}\right.$ emission) is the denitrifying capacity of the soil, especially the capacity of soil to produce $\mathrm{N}_{2} \mathrm{O}$.

Burford and Bremner (1975) described denitrification capacity (DC) as a process directly related to the total C content, and also to the water-soluble and mineralizable $\mathrm{C}$ in the reaction of $\mathrm{NO}_{3}{ }^{-}$-treated soil incubated at $20^{\circ} \mathrm{C}$ for 7 days with a $\mathrm{C}_{2} \mathrm{H}_{2}$ block (as a the sum of $\mathrm{N}_{2} \mathrm{O}$ and $\mathrm{N}_{2}$ forms). In other words, it is a process occurring in soil characterized by natural availability of organic $\mathrm{C}$ and enriched in $\mathrm{NO}_{3}{ }^{-}$.

Our studies introduce the concept of actual denitrification leading to $\mathrm{N}_{2} \mathrm{O}$ formation without addition of $\mathrm{NO}_{3}{ }^{-}$ $\left(\mathrm{aD}_{\mathrm{N}_{2} \mathrm{O}}\right)$ and the concept of denitrification capacity leading to $\mathrm{N}_{2} \mathrm{O}$ formation with addition of $\mathrm{NO}_{3}{ }^{-}\left(\mathrm{DC}_{\mathrm{N}_{2} \mathrm{O}}\right)$. The two concepts of $\mathrm{aD}_{\mathrm{N}_{2} \mathrm{O}}$ and $\mathrm{DC}_{\mathrm{N}_{2} \mathrm{O}}$ are defined as $\mathrm{NO}_{3}{ }^{-}$reduction in conditions of a natural organic $\mathrm{C}$ content as a source of $\mathrm{C}$ and electrons in denitrification. The difference in determination of these two parameters is incubation with (DC $\left.\mathrm{N}_{2} \mathrm{O}\right)$ or without $\left(\mathrm{aD}_{\mathrm{N}_{2} \mathrm{O}}\right)$ additional $\mathrm{NO}_{3}{ }^{-}$. The $\mathrm{aD}_{\mathrm{N}_{2} \mathrm{O}}$ and $\mathrm{DC}_{\mathrm{N}_{2} \mathrm{O}}$ were determined without a $\mathrm{C}_{2} \mathrm{H}_{2}$ block, in contrast to DC described by Burford and Bremner (1975).

In the current study, denitrification of long-term airdried stored soil samples was compared with fresh air-dried samples collected from the same plots and incubated under flooded and fully controlled conditions. The objective of the experiment was to test the impact of prolonged drought conditions and soil type on the denitrification capacity and actual denitrification leading to $\mathrm{N}_{2} \mathrm{O}$ formation. It is hypothesized that prolonged dry conditions will increase the denitrification capacity due to biodegradation of not easily accessible organic carbon caused by long storage time.

\section{MATERIALS AND METHODS}

Six soil samples from Ap horizon of Silty loam texture collected approximately 25 years prior to the start of the study from mineral soils used for agriculture in Poland, stored under air-dry conditions in the Soil Bank in the Institute of Agrophysics, Polish Academy of Sciences, Lublin, Poland, and fresh soils resampled at the same sites in 2012 (stored under air-dry conditions up to incubation) were used in the study.

For measurement of the actual denitrification $\mathrm{aD}_{\mathrm{N}_{2} \mathrm{O}}$ and the denitrification capacity $\mathrm{DC}_{\mathrm{N}_{2} \mathrm{O}}$, the stored and fresh soils were divided into two parts. 5-g portions of dry soils were placed in $22 \mathrm{~cm}^{3}$ glass flasks and flooded with $5 \mathrm{ml}$ of distillated water. To determine the $\mathrm{aD}_{\mathrm{N}_{2} \mathrm{O}}$ and $\mathrm{DC}_{\mathrm{N}_{2} \mathrm{O}}$, the soil samples were prepared according to the following variants:

I - soils stored (for 25 years) in the Bank of Soil (S) and fresh air-dried soils collected from the same locations as the stored samples ( F) with water addition - the results of soil incubation corresponding to actual denitrification leading to $\mathrm{N}_{2} \mathrm{O}$ formation $\left(\mathrm{aD}_{\mathrm{N}_{2} \mathrm{O}}\right)$,

II - soils ( $\mathrm{S}$ and $\mathrm{F}$ ) with water and $\mathrm{NO}_{3}{ }^{-}$addition - the results of soil incubation corresponding to denitrification capacity leading to $\mathrm{N}_{2} \mathrm{O}$ formation $-\left(\mathrm{DC}_{\mathrm{N}_{2} \mathrm{O}}\right)$. $\mathrm{NO}_{3}{ }^{-}$was added as $\mathrm{KNO}_{3}$ at the rate of $3 \mathrm{mg}$ of $\mathrm{NO}_{3}{ }^{-}-\mathrm{N}$ per $10 \mathrm{~g}$ of dry soil (Šimek et al., 2004).

The flasks with the soils were tightly sealed with rubber stoppers and incubated in ambient air. The initial concentration of $\mathrm{O}_{2}$ in the gas headspace at the beginning of the incubation was $20.9 \% \mathrm{v} / \mathrm{v}$. Paraffin films were placed over the stoppers to ensure hermetic sealing. The soils were incubated at $20^{\circ} \mathrm{C}$ for 7 days (Włodarczyk et al., 2005).

After 1,2, and 7 days of incubation, the concentrations of $\mathrm{N}_{2} \mathrm{O}$ and $\mathrm{CO}_{2}$ in the headspace were determined with a gas chromatograph (Shimadzu GC-2014, Japan) equipped with a split-splitless injector with an injection divider in two column types and two types of detectors depending on the analysed gas. $100-\mu 1$ samples were dosed automatically by an auto-sampler AOC 5000. Helium was used as a carrier gas (column flow rate: $5 \mathrm{ml} \mathrm{min}^{-1}$ ). The concentration of $\mathrm{N}_{2} \mathrm{O}$ was analyzed using an electron capture detector (ECD). Separation of the gas samples was performed on the Supel PLOT-Q ${ }^{\text {TM }} 30 \mathrm{~m}$ x $0.32 \mathrm{~mm}$ column (manufacturer Supelco). The concentration of $\mathrm{CO}_{2}$ was measured on the same column using a flame ionization detector (FID). The column oven temperature was $35^{\circ} \mathrm{C}$. All detectors operated at $200^{\circ} \mathrm{C}$. The concentrations of $\mathrm{N}_{2} \mathrm{O}-\mathrm{N}$ and $\mathrm{CO}_{2}-\mathrm{C}$ were corrected for gas dissolved in water using the literature values of Bunsen 
absorption coefficients. The results obtained were calculated per $\mathrm{kg}$ of dry soil. The amount of $\mathrm{N}_{2} \mathrm{O}$ (incomplete denitrification) and $\mathrm{CO}_{2}$ release were determined during the 7 days of incubation at different stages of the cumulative curve of $\mathrm{N}_{2} \mathrm{O}$ and $\mathrm{CO}_{2}$ release. The $\mathrm{N}_{2} \mathrm{O}$ and $\mathrm{CO}_{2}$ release was expressed as the maximum cumulative amount of $\mathrm{N}_{2} \mathrm{O}-\mathrm{N}$ and $\mathrm{CO}_{2}-\mathrm{C} \mathrm{mg} \mathrm{kg}{ }^{-1}$ soil for 7 days of incubation.

The $\mathrm{NO}_{3}{ }^{-}$content in soil was measured in $5 \mathrm{~g}$ of air-dry soil suspended in $105 \mathrm{ml}$ of $0.025 \mathrm{~N} \mathrm{CaCl}_{2}$. The suspension was shaken for $2 \mathrm{~h}$. The filtered solution of $\mathrm{NO}_{3}{ }^{-}$ions was determined using a flow spectrophotometer (FIA-Star 5010 Analyzer FOSS Tecator). Soil aeration conditions were estimated by the redox potential (Eh) as described by Gliński and Stępniewski (1985) (Table 1).

Particle size distribution (PSD) was measured using a laser diffractometer Mastersizer 2000 (Malvern, UK) with a Hydro G dispersion unit. The measuring range was $0.02 \mu \mathrm{m}$ $-2 \mathrm{~mm}$. The following parameters were set: pump speed 1750 r.p.m. and the stirrer speed - 700 r.p.m. (Sochan et al., 2012). Ultrasonification (maximum power $-35 \mathrm{~W}$ for $4 \mathrm{~min}$ ) was used for aggregate dispersion (Ryżak and Bieganowski, 2011). The procedure of decreasing obscuration (to the maximum level of $20 \%$ ) was used when the obscuration was too high after ultrasonification (Bieganowski et al., 2010). Mie theory was used for recalculation of light intensity into PSD with the following indices: soil refraction index 1.52 , soil absorption index 0.1 , and water refraction index 1.33 . The measurements were carried out in 3 replications ( $1 \mathrm{~min}$ each measurement $-30 \mathrm{~s}$ of red and $30 \mathrm{~s}$ of blue light) for each of the three samplings (for each soil) (Table 1).

Determination of other soil properties included $\mathrm{C}_{\text {org }}$ (TOC-analyzer); $\mathrm{pH}$ was determined in the aqueous suspension of soil $(\mathrm{v} / \mathrm{v}=1 / 1)$ using a $\mathrm{pH}$-meter (PIONeer $\mathrm{pH}$ Radiometer Copenhagen).

The results were statistically analyzed. Linear $(y=a+b x)$, multiplicative $\left(y=a x^{b}\right)$, exponential $\left(y=e^{a+b x}\right)$, and logarithmic $(y=a l n x+b)$ models were used in regression analysis, and in each case the model with the highest $\mathrm{R}^{2}$ was selected as the best fit for the experimental data, using Microsoft Office Excel 2007. Statgraphics program was used for analysis of variance.

\section{RESULTS}

The basic soils characteristics are presented in Table 1. The Mollic Gleysols (MG), Eutric Cambisols (EC), Haplic Phaeozems (HPh), Haplic Podzols (HP), Rendzic Leptosols (RL), and Distric Fluvisols (DF) were formed of silt loam. The soils used for the laboratory experiment were characterized by a wide spectrum of native $\mathrm{C}_{\text {org }}$ contents ranging from 1.1 (HP) to $3.82(\mathrm{MG})$ and from 1.31 (EC) to 3.79 (MG), for the stored and fresh soils, respectively. The investigated soils were characterized by a wide spectrum of the $\mathrm{pH}$ reaction value ranging from slightly acidic 5.68 (EC) to alkaline - 7.25 (RL) and from acidic - 5.48 (DF) to neutral $-7.11(\mathrm{RL})$. The native $\mathrm{NO}_{3}{ }^{-}$content in the stored soils was

T a b l e 1. Basic properties and particle size distributions of stored $(\mathrm{S})$ and fresh $(\mathrm{F})$ soils of Silt loam

\begin{tabular}{|c|c|c|c|c|c|c|c|c|}
\hline \multirow{2}{*}{ Soil No. ${ }^{1}$} & \multirow{2}{*}{ Soil units } & \multicolumn{3}{|c|}{$\begin{array}{l}\text { Granulometric composition (\%) } \\
\text { (dia in } \mathrm{mm})\end{array}$} & \multirow{2}{*}{$\frac{\mathrm{C}_{\text {org }}}{\%}$} & \multirow{2}{*}{$\frac{\mathrm{NO}_{3}{ }^{-}-\mathrm{N}^{2}}{\mathrm{mg} \mathrm{kg}^{-1}}$} & \multirow[t]{2}{*}{$\mathrm{pH}^{3}$} & \multirow{2}{*}{$\frac{\mathrm{Eh}^{4}}{\mathrm{mV}}$} \\
\hline & & sand & silt & clay & & & & \\
\hline \multirow[b]{2}{*}{145} & \multirow[b]{2}{*}{ Mollic Gleysols } & \multirow[b]{2}{*}{34} & \multirow[b]{2}{*}{59} & \multirow[b]{2}{*}{7} & $3.82^{\mathrm{S}}$ & $0.81^{\mathrm{S}}$ & $5.75^{\mathrm{S}}$ & $290^{\mathrm{S}}$ \\
\hline & & & & & $3.79^{\mathrm{F}}$ & $5.86^{\mathrm{F}}$ & $6.70^{\mathrm{F}}$ & $232^{\mathrm{F}}$ \\
\hline \multirow[b]{2}{*}{553} & \multirow[b]{2}{*}{ Eutrick Cambisols } & \multirow[b]{2}{*}{31} & \multirow[b]{2}{*}{63} & \multirow[b]{2}{*}{6} & $1.37^{\mathrm{S}}$ & $0.28^{\mathrm{S}}$ & $5.68^{\mathrm{S}}$ & $296^{\mathrm{S}}$ \\
\hline & & & & & $1.31^{\mathrm{F}}$ & $0.13^{\mathrm{F}}$ & $5.53^{\mathrm{F}}$ & $342^{\mathrm{F}}$ \\
\hline \multirow[b]{2}{*}{601} & \multirow[b]{2}{*}{ Haplic Phaeozems } & \multirow[b]{2}{*}{14} & \multirow[b]{2}{*}{79} & \multirow[b]{2}{*}{7} & $1.00^{\mathrm{S}}$ & $0.31^{\mathrm{S}}$ & $7.12^{\mathrm{S}}$ & $207^{\mathrm{S}}$ \\
\hline & & & & & $1.33^{\mathrm{F}}$ & $0.91^{\mathrm{F}}$ & $5.68^{\mathrm{F}}$ & $365^{\mathrm{F}}$ \\
\hline \multirow[b]{2}{*}{633} & \multirow[b]{2}{*}{ Haplic Podzols } & \multirow[b]{2}{*}{30} & \multirow[b]{2}{*}{63} & \multirow[b]{2}{*}{7} & $1.10^{\mathrm{S}}$ & $3.4^{\mathrm{S}}$ & $5.74^{\mathrm{S}}$ & $263^{\mathrm{S}}$ \\
\hline & & & & & $1.38^{\mathrm{F}}$ & $0.68^{\mathrm{F}}$ & $6.50^{\mathrm{F}}$ & $299^{\mathrm{F}}$ \\
\hline \multirow[b]{2}{*}{724} & \multirow[b]{2}{*}{ Rendzic Leptosols } & \multirow[b]{2}{*}{39} & \multirow[b]{2}{*}{54} & \multirow[b]{2}{*}{7} & $1.79^{\mathrm{S}}$ & $2.96^{\mathrm{S}}$ & $7.25^{\mathrm{S}}$ & $197^{\mathrm{S}}$ \\
\hline & & & & & $2.80^{\mathrm{F}}$ & $1.53^{\mathrm{F}}$ & $7.11^{\mathrm{F}}$ & $285^{\mathrm{F}}$ \\
\hline \multirow[b]{2}{*}{941} & \multirow[b]{2}{*}{ Distric Fluvisols } & \multirow[b]{2}{*}{39} & \multirow[b]{2}{*}{55} & \multirow[b]{2}{*}{6} & $1.58^{\mathrm{S}}$ & $3.42^{\mathrm{S}}$ & $5.72^{\mathrm{S}}$ & $262^{\mathrm{S}}$ \\
\hline & & & & & $1.98^{\mathrm{F}}$ & $6.99^{\mathrm{F}}$ & $5.48^{\mathrm{F}}$ & $296^{\mathrm{F}}$ \\
\hline
\end{tabular}

${ }^{1}$ Soil No. from the Bank of Soil, ${ }^{2}$ endogenous nitrate content, ${ }^{3} \mathrm{pH}$ value from the 0 day of incubation, ${ }^{4}$ Eh value from the 0 day of incubation. 
in a range from 0.28 (EC) to 3.42 (DF) while in the fresh samples from 0.13 (EC) to 6.99 (DF). At the initial phase of incubation (0 day) the redox potential value (Eh) ranged from $(+197)$ for RL to $(+296)$ for EC for stored soils while for the fresh soils the range was from $(+232)$ for MG to $(+365)$ for $\mathrm{HPh}$.

The differences between the native $\mathrm{NO}_{3}{ }^{-}$reduction in the control stored and fresh soils are shown in Table 2. The native $\mathrm{NO}_{3}{ }^{-}$content described as $\%$ of its reduction during 7 days of incubation ranged from 0 (MG) to $100 \%$ (HP, RL, and DF) for the stored soils and from $40.7(\mathrm{HPh})$ to $100 \%$ (EC) for the fresh soils. The percent of $\mathrm{NO}_{3}{ }^{-}$denitrified to $\mathrm{N}_{2} \mathrm{O}$ was zero for the stored soils while for fresh soils it ranged from 0 (MG and $\mathrm{RL}$ ) to $100 \%$ (EC, $\mathrm{HPh}, \mathrm{HP}$, and DF) depending on the type of soil.

The differences between the added $\mathrm{NO}_{3}{ }^{-}$reduction in the stored and fresh soils are shown in Table 3. The added $\mathrm{NO}_{3}{ }^{-}$content described as $\%$ of its reduction during 7 days of incubation ranged from 31.1 (HP) to $98.1 \%$ (MG) for the stored soils and from 49.0 (HP) to $98.1 \%(\mathrm{MG})$ for the fresh soils. The percent of $\mathrm{NO}_{3}{ }^{-}$denitrified to $\mathrm{N}_{2} \mathrm{O}$ ranged from $16.2(\mathrm{HPh})$ to $46.1 \%(\mathrm{RL})$ and from $5.4(\mathrm{HP})$ to $31.4 \%(\mathrm{RL})$, for the stored and fresh soils, respectively, depending on the type of soils and length of storage.

Figure 1 shows the course of two types of denitrification $-\mathrm{aD}_{\mathrm{N}_{2} \mathrm{O}}$ and $\mathrm{DC}_{\mathrm{N}_{2} \mathrm{O}}$ of the soil without and with the addition of $\mathrm{NO}_{3}{ }^{-}$(respectively) during incubation under flooded conditions. The studied soils differed in terms of the amount of $\mathrm{N}_{2} \mathrm{O}$ released during $\mathrm{aD}_{\mathrm{N}_{2} \mathrm{O}}$. There was no $\mathrm{N}_{2} \mathrm{O}$ release during incubation without additional $\mathrm{NO}_{3}{ }^{-}$from the stored soils (Table 2 and Fig. 1 inserts). The fresh soils had very low $\mathrm{aD}_{\mathrm{N}_{2} \mathrm{O}}$. The cumulative $\mathrm{N}_{2} \mathrm{O}$ release during $\mathrm{aD}_{\mathrm{N}_{2} \mathrm{O}}$ from the fresh soils ranged from-0 (MG and RL) to 2.84 (HPh) $\mathrm{mg} \mathrm{N}_{2} \mathrm{O}-\mathrm{N} \mathrm{kg}^{-1}$ of soil (Table 2 and Fig. 1 inserts).

The $\mathrm{NO}_{3}{ }^{-}$addition caused a very intense increase in the amount of $\mathrm{N}_{2} \mathrm{O}$ released in both the stored and fresh soils and ranged from $48.8(\mathrm{HPh})$ to $139.6(\mathrm{RL}) \mathrm{mg} \mathrm{N} \mathrm{N}_{2} \mathrm{O}-\mathrm{N} \mathrm{kg}^{-1}$ of soil for the stored soils. For the fresh soils, it ranged from 16.32 (HP) to $95.5 \mathrm{mg}$ (RL) $\mathrm{N}_{2} \mathrm{O}-\mathrm{N} \mathrm{kg}^{-1}$ of soil (Table 3 and Fig. 1). The amount of $\mathrm{N}_{2} \mathrm{O}$ released from the stored soils was significantly higher than that of the fresh soils, except for $\mathrm{HPh}$ No. 601 (Fig. 1c).

Consumption of $\mathrm{N}_{2} \mathrm{O}$ in the headspace was observed in some of the fresh samples both in $\mathrm{aD}_{\mathrm{N}_{2} \mathrm{O}}$ (Fig. 1 b, c, $\mathrm{f}$ inserts) and $\mathrm{DC}_{\mathrm{N}_{2} \mathrm{O}}$ (Fig. $1 \mathrm{a}, \mathrm{d}, \mathrm{e}$ ) and in one of the stored soils for $\mathrm{DC}_{\mathrm{N}_{2} \mathrm{O}}(99.6 \%$ for $\mathrm{MG}$ (Fig. 1 a) after its maximum cumulative amount (between 1 and 3 day of incubation). The percent of $\mathrm{N}_{2} \mathrm{O}$ consumption on 7 day of incubation ranged from $0(\mathrm{HP})$ to $89.9 \%(\mathrm{HPh})$ for $\mathrm{aD}_{\mathrm{N}_{2} \mathrm{O}}$ in the fresh soils and from 0 (EC, $\mathrm{HPh}$ and $\mathrm{DF}$ ) to $32.6(\mathrm{HP})$ for $\mathrm{DC}_{\mathrm{N}_{2} \mathrm{O}}$ in the fresh soils (Table 2 and 3 ).

There was a significant positive correlation between the cumulative $\mathrm{N}_{2} \mathrm{O}$ release and reduced $\mathrm{NO}_{3}{ }^{-}(\mathrm{R}=0.94, \mathrm{p}<0.01$ and $\mathrm{R}=0.93, \mathrm{p}<0.001$ for stored and fresh soils enriched with $\mathrm{NO}_{3}{ }^{-}$, respectively).

T a b l e 2. $\mathrm{NO}_{3}{ }^{-}$reduction, $\mathrm{CO}_{2}$ release, $\mathrm{N}_{2} \mathrm{O}$ release and consumption in stored $(\mathrm{S})$ and fresh $(\mathrm{F})$ control soils

\begin{tabular}{|c|c|c|c|c|c|c|c|}
\hline \multirow{3}{*}{$\begin{array}{l}\text { Soil units } \\
\text { (No.) }\end{array}$} & \multirow{3}{*}{$\begin{array}{l}\text { Length } \\
\text { of soils } \\
\text { storage }\end{array}$} & \multicolumn{2}{|c|}{$\mathrm{NO}_{3}^{-}$} & \multicolumn{2}{|c|}{$\mathrm{N}_{2} \mathrm{O}-$ cumulative } & \multicolumn{2}{|c|}{$\mathrm{CO}_{2}-$ cumulative } \\
\hline & & Reduction & $\begin{array}{l}\text { Denitrified } \\
\text { to } \mathrm{N}_{2} \mathrm{O}\end{array}$ & $\begin{array}{c}\text { Maximum } \\
\text { release }\end{array}$ & Consumption & $\begin{array}{l}\text { Maximum } \\
\text { release }\end{array}$ & $\mathrm{S} / \mathrm{F}$ \\
\hline & & $\%$ & & $\mathrm{mg} \mathrm{kg}^{-1}$ & $\%$ & $\mathrm{mg} \mathrm{kg}^{-1}$ & \\
\hline \multirow{2}{*}{ Mollic Gleysols (145) } & $\mathrm{S}$ & 0 & 0 & 0 & 0 & 529.0 & 5.1 \\
\hline & $\mathrm{F}$ & 93.5 & 0 & 0 & 0 & 103.8 & \\
\hline \multirow{2}{*}{ Eutrick Cambisols (553) } & S & 46.4 & 0 & 0 & 0 & 142.4 & 0.9 \\
\hline & $\mathrm{F}$ & 100 & 100 & 0.38 & 47.0 & 155.2 & \\
\hline \multirow{2}{*}{ Haplic Phaeozems (601) } & $\mathrm{S}$ & 54.8 & 0 & 0 & 0 & 138.6 & 1.0 \\
\hline & $\mathrm{F}$ & 40.7 & 100 & 2.84 & 89.9 & 137.1 & \\
\hline \multirow{2}{*}{ Haplic Podzols (633) } & S & 100 & 0 & 0 & 0 & 126.6 & 2.5 \\
\hline & $\mathrm{F}$ & 50.0 & 100 & 1.45 & 0 & 50.8 & \\
\hline \multirow{2}{*}{ Rendzic Leptosols (724) } & S & 100 & 0 & 0 & 0 & 80.5 & 0.5 \\
\hline & $\mathrm{F}$ & 90.1 & 0 & 0 & 0 & 160.1 & \\
\hline \multirow{2}{*}{ Distric Fluvisols (941) } & S & 100 & 0 & 0 & 0 & 179.9 & 1.0 \\
\hline & F & 62.7 & 100 & 2.09 & 58.0 & 187.6 & \\
\hline
\end{tabular}

$\mathrm{S} / \mathrm{F} \mathrm{CO}_{2}$ ratio - the ratio of $\mathrm{CO}_{2}$ release from stored to fresh soils. 

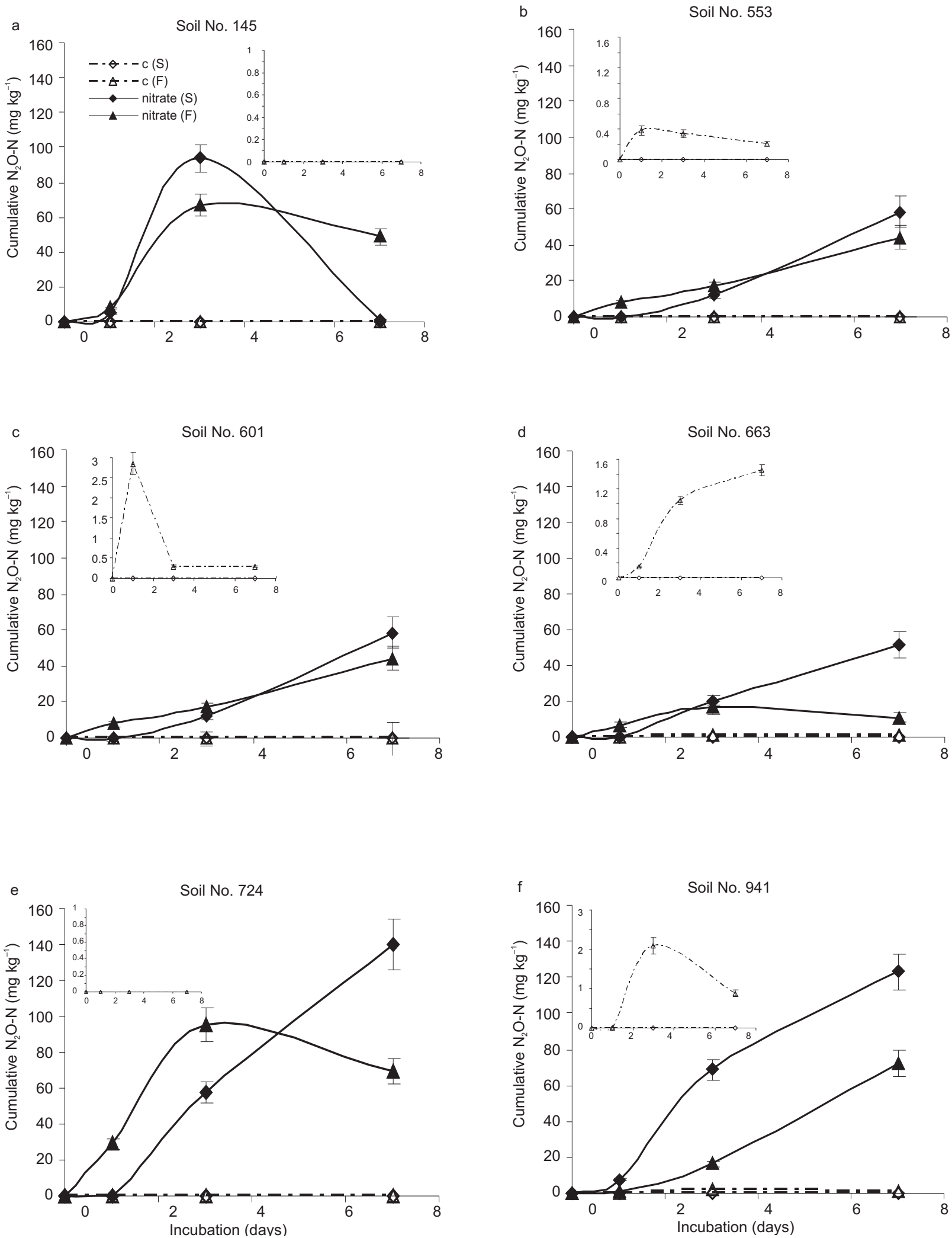

Fig. 1. Cumulative $\mathrm{N}_{2} \mathrm{O}-\mathrm{N}$ release and consumption from: a - Mollic Gleysols (No. 145), b - Eutric Cambisols (No. 553), c - Haplic Phaeozems (No. 601), d- Haplic Podzols (No. 633), e-Rendzic Leptosols (No. 724), and f- Distric Fluvisols (No. 941) as a function of incubation time (inserts show the curves of the control soils). 
T a b l e 3. $\mathrm{NO}_{3}{ }^{-}$reduction, $\mathrm{CO}_{2}$ release, $\mathrm{N}_{2} \mathrm{O}$ release and consumption in stored (S) and resampled soils (F) enriched with $\mathrm{NO}_{3}^{-}$soil

\begin{tabular}{|c|c|c|c|c|c|c|c|c|}
\hline \multirow{3}{*}{$\begin{array}{l}\text { Soil units } \\
\text { (No.) }\end{array}$} & \multirow{3}{*}{$\begin{array}{l}\text { Length } \\
\text { of soils } \\
\text { storage }\end{array}$} & \multicolumn{2}{|c|}{$\mathrm{NO}_{3}^{-}$} & \multicolumn{3}{|c|}{$\mathrm{N}_{2} \mathrm{O}$ - cumulative } & \multicolumn{2}{|c|}{$\mathrm{CO}_{2}$ - cumulative } \\
\hline & & Reduction & $\begin{array}{c}\text { Denitrified } \\
\text { to } \mathrm{N}_{2} \mathrm{O}\end{array}$ & $\begin{array}{c}\text { Maximum } \\
\text { release }\end{array}$ & $\mathrm{S} / \mathrm{F}$ & Consumption & $\begin{array}{c}\text { Maximum } \\
\text { release }\end{array}$ & $\mathrm{S} / \mathrm{F}$ \\
\hline & & $\%$ & & $\mathrm{mg} \mathrm{kg}^{-1}$ & ratio & $\%$ & $\mathrm{mg} \mathrm{kg}^{-1}$ & ratio \\
\hline \multirow{2}{*}{ Mollic Gleysols (145) } & S & 98.1 & 31.1 & 93.6 & \multirow{2}{*}{1.4} & 99.2 & 557.5 & \multirow{2}{*}{6.1} \\
\hline & $\mathrm{F}$ & 98.1 & 21.9 & 66.9 & & 27.3 & 91.2 & \\
\hline \multirow{2}{*}{ Eutrick Cambisols (553) } & $\mathrm{S}$ & 57.3 & 19.5 & 59.6 & \multirow{2}{*}{1.3} & 0 & 117.0 & \multirow{2}{*}{0.9} \\
\hline & $\mathrm{F}$ & 51.6 & 14.7 & 44.2 & & 0 & 133,6 & \\
\hline \multirow{2}{*}{ Haplic Phaeozems (601) } & $\mathrm{S}$ & 56.7 & 16.2 & 48.8 & \multirow{2}{*}{1.3} & 0 & 138.5 & \multirow{2}{*}{1.2} \\
\hline & $\mathrm{F}$ & 55.6 & 12.6 & 37.8 & & 0 & 115.8 & \\
\hline \multirow{2}{*}{ Haplic Podzols (633) } & $\mathrm{S}$ & 31.1 & 16.9 & 51.5 & \multirow{2}{*}{3.2} & 0 & 114.9 & \multirow{2}{*}{1.5} \\
\hline & $\mathrm{F}$ & 49.0 & 5.4 & 16.32 & & 32.6 & 75.1 & \\
\hline \multirow{2}{*}{ Rendzic Leptosols (724) } & $\mathrm{S}$ & 91.9 & 46.1 & 139.6 & \multirow{2}{*}{1.5} & 0 & 58.7 & \multirow{2}{*}{0.4} \\
\hline & $\mathrm{F}$ & 97.8 & 31.4 & 95.5 & & 27.2 & 152.3 & \\
\hline \multirow{2}{*}{ Distric Fluvisols (941) } & $\mathrm{S}$ & 64.2 & 40.5 & 122.9 & \multirow{2}{*}{1.7} & 0 & 200.5 & \multirow{2}{*}{1.0} \\
\hline & $\mathrm{F}$ & 74.3 & 23.9 & 72.2 & & 0 & 207.5 & \\
\hline
\end{tabular}

$\mathrm{S} / \mathrm{F} \mathrm{N}_{2} \mathrm{O}$ ratio - the ratio of $\mathrm{N}_{2} \mathrm{O}$ release from stored to fresh soils, $\mathrm{S} / \mathrm{F} \mathrm{CO}_{2}$ ratio - the ratio of $\mathrm{CO}_{2}$ release from stored to fresh soils.

There was also a close correlation between the cumulative release of $\mathrm{N}_{2} \mathrm{O}$ and $\mathrm{C}_{\text {org }}$ content $(\mathrm{R}=0.93, \mathrm{p}<0.01$; and $\mathrm{R}=0.92, \mathrm{p}<0.01$ for the stored and fresh soils enriched with $\mathrm{NO}_{3}{ }^{-}$, respectively).

Differences in the cumulative $\mathrm{CO}_{2}$ release between the stored and fresh soils were found during the entire incubation period. The differences were statistically significant except for EC No. 553, HPh No. 601, and DF No. 941 for the control soils. In enriched $\mathrm{NO}_{3}{ }^{-}$, no statistically significant differences were found only in two soils (EC No. 553, and DF No. 941). The cumulative $\mathrm{CO}_{2}$ release from control soils ranged from 80.5 (RL) to 529.0 (MG) $\mathrm{mg} \mathrm{C} \mathrm{kg}^{-1}$ and from 50.8 (HP) to 187.6 (DF) $\mathrm{mg} \mathrm{C} \mathrm{kg}^{-1}$ for the stored and fresh soils, respectively.

The $\mathrm{NO}_{3}{ }^{-}$addition to soils slightly changed the respiration activity of the soils compared with the control soils and the amount of released $\mathrm{CO}_{2}$ ranged from 58.7 (RP) to 557.5 (MG) $\mathrm{mg} \mathrm{C} \mathrm{kg}^{-1}$ for the stored soils and from 75.1 (HP) to 207.5 (DF) $\mathrm{mg} \mathrm{C} \mathrm{kg}^{-1}$ for the fresh soils.

Regression analysis for respiration of soils showed a significant positive relationship between the cumulative $\mathrm{CO}_{2}$ release and $\mathrm{C}_{\text {org }}(\mathrm{R}=0.92, \mathrm{p}<0.01)$ for the control stored soils enriched with $\mathrm{NO}_{3}{ }^{-}$. There was no significant relationship for the fresh soil samples.

\section{DISCUSSION}

Understanding how dry/wet cycles affect $\mathrm{C}$ and $\mathrm{N}$ transformations is important in predicting soil organic matter (SOM) dynamics, determining the effects of climate change on greenhouse gas emissions (principally $\mathrm{CO}_{2}$ and $\mathrm{N}_{2} \mathrm{O}$ ) from soils ( $\mathrm{Wu}$ and Brookes, 2005).

However, prolonged dry soil conditions followed by flooding of the soil may cause much larger changes in the dynamics of $\mathrm{C}$ and $\mathrm{N}$ than very short-term soil dry/wet cycles. A change in the availability of $\mathrm{C}$ alters the $\mathrm{N}$ transformation associated with biogenic gas $\mathrm{CO}_{2}$ and $\mathrm{N}_{2} \mathrm{O}$ production, especially under conditions of hypoxia. Determination of the $\mathrm{aD}_{\mathrm{N}_{2} \mathrm{O}}$ and $\mathrm{DC}_{\mathrm{N}_{2} \mathrm{O}}$ allowed answering two main questions about the influence of long-term storage compared to fresh air-dried soils on:

- actual denitrification $\left(\mathrm{aD}_{\mathrm{N}_{2} \mathrm{O}}\right)$ leading to $\mathrm{N}_{2} \mathrm{O}$ formation with a natural content of $\mathrm{N}$ and $\mathrm{C}$ in flooded soil,

- the capacity of denitrification $\left(\mathrm{DC}_{\mathrm{N}_{2} \mathrm{O}}\right.$ ) to $\mathrm{N}_{2} \mathrm{O}$ formation where the process is not limited by deficiency of $\mathrm{NO}_{3}{ }^{-}$ after flooding from the standpoint of environmental protection.

This problem increases with the problem of global warming and the prolonged period of drought, followed by heavy rain and flooding. The studied soils showed very low 
$\mathrm{aD}_{\mathrm{N}_{2} \mathrm{O}}$ irrespective of the length of storage after flooding. There was no $\mathrm{N}_{2} \mathrm{O}$ release from the long stored soils, but the fresh soils had also very low $\mathrm{aD}_{\mathrm{N}_{2} \mathrm{O}}$. In two soils (MG No. 145 and RL No. 724), $\mathrm{N}_{2} \mathrm{O}$ was not released from the fresh soils. In the rest of the fresh soils, released $\mathrm{N}_{2} \mathrm{O}$ did not exceed $3 \mathrm{mg} \mathrm{N}_{2} \mathrm{O}-\mathrm{N} \mathrm{kg}^{-1}$. It should be emphasized that there was no emission of $\mathrm{N}_{2} \mathrm{O}$ from the stored soil and two fresh soils in the case of the native $\mathrm{NO}_{3}{ }^{-}$content. Probably, the low $\mathrm{NO}_{3}{ }^{-}$content in these soils was below the threshold concentration for $\mathrm{N}_{2} \mathrm{O}$ production. Włodarczyk et al. (2004) investigated $\mathrm{NO}_{3}{ }^{-}$stability in loess soils under anaerobic conditions and found no denitrification below $25 \mathrm{mg}$ $\mathrm{NO}_{3}{ }^{-}-\mathrm{N} \mathrm{kg}^{-1}$. In turn, Senbayrama et al. (2012) found that high respiration in treatments with maize straw and sucrose resulted in a transient peak in $\mathrm{N}_{2} \mathrm{O}$ emission, declining rapidly towards zero once the $\mathrm{NO}_{3}{ }^{-}$concentrations dropped below $20 \mathrm{mg} \mathrm{NO}_{3}{ }^{-}-\mathrm{N} \mathrm{kg}^{-1}$ dry soil. Therefore, the low content of $\mathrm{NO}_{3}^{-}$was a factor clearly limiting the denitrification process, in particular to the form of $\mathrm{N}_{2} \mathrm{O}$. The results led to the conclusion that these conditions were not conducive to growth of heterotrophic bacteria such as denitrifiers. On the other hand, it cannot be excluded that the $\mathrm{NO}_{3}{ }^{-}$was denitrified entirely to $\mathrm{N}_{2}$. Generally, by comparing the $\mathrm{NO}_{3}{ }^{-}$content in stored and fresh soils, it can be expected that the $\mathrm{N}_{2} \mathrm{O}$ relese will either fall or rise, due to the length of storage of the soil and type of soils.

While comparing the amount of $\mathrm{N}_{2} \mathrm{O}$ released from EC No. 533, HPh No. 601, and HP No. 633 of the recently sampled soils with the amount of their native $\mathrm{NO}_{3}{ }^{-}$amount, it can be suspected that part of $\mathrm{N}_{2} \mathrm{O}$ was derived from the process of nitrification, because the amount of $\mathrm{N}_{2} \mathrm{O}-\mathrm{N}$ exceeded the amount of $\mathrm{N}$ contained in $\mathrm{NO}_{3}{ }^{-}$. These soils provide evidence for low nitrification activity under a low natural $\mathrm{NO}_{3}{ }^{-}$content. In flooded soils, there is a thin oxygenated layer at the interface between air and water, which may occur at the same time as the processes of nitrification and denitrification ( $\mathrm{Yu}$ et al., 2006). Nitrification and denitrification are the major sources of $\mathrm{N}_{2} \mathrm{O}$ emissions from soils (Zhang et al., 2011)

In the case of $\mathrm{NO}_{3}{ }^{-}$addition, the amount of released $\mathrm{N}_{2} \mathrm{O}\left(\mathrm{PD}_{\mathrm{N}_{2} \mathrm{O}}\right)$ significantly increased and depended on the length of storage of soils and type of soils. Much higher $\mathrm{N}_{2} \mathrm{O}$ release was observed from the stored soils compared with the fresh samples. The ratio of $\mathrm{N}_{2} \mathrm{O}$ released from the stored to fresh soils was always higher than one $\left(\mathrm{S} / \mathrm{F} \mathrm{N}_{2} \mathrm{O}\right.$ ratio) and ranged from 1.3 (EC and $\mathrm{HPh}$ ) to $3.2(\mathrm{HP})$. It can be expected that the $\mathrm{NO}_{3}{ }^{-}$addition to the flooded soil after a long drought led to the development of active denitrifying bacteria under easily accessible $\mathrm{C}$ and N. Harrison-Kirk et al. (2013) studied $\mathrm{CO}_{2}$ and $\mathrm{N}_{2} \mathrm{O}$ production during sequential dry/wet cycles at laboratory incubation. Following rewetting, the very dry and moderately dry soils produced a short-term $\mathrm{C}$ mineralization flush that was, on average, 30 and $15 \%$ greater, respectively, than in wet (field capacity) soils. On average, the total $\mathrm{N}_{2} \mathrm{O}$ emissions from dry/wet treatments imposed on silt loam and clay loam soils were $33 \%$ and $270 \%$ greater, respectively, than at the field capacity moisture content, although the effect varied greatly depending on the SOC content. $\mathrm{NO}_{3}{ }^{-}$is very mobile in soil; it may rapidly diffuse into soil compartments with low oxygen contents where it may promote biological denitrification. Thus, next to degradable carbon compounds, the $\mathrm{NO}_{3}{ }^{-}$concentration in the soil solution is another major factor limiting denitrification (Senbayrama et al., 2012).

The substantially higher activity of $\mathrm{PD}_{\mathrm{N}_{2} \mathrm{O}}$ in the fresh soils than in the stored soils observed after the first three days of incubation in the investigated soils demonstrates a higher adaptive ability of denitrifying bacteria to changes in the availability of $\mathrm{C}$ and oxygen $\left(\mathrm{O}_{2}\right)$ in the headspace and soil suspension. A rapid change was observed in the respiration type from aerobic to $\mathrm{NO}_{3}{ }^{-}$respiration where $\mathrm{NO}_{3}{ }^{-}$was used as an alternative electron acceptor instead of oxygen. The results showed that the denitrifying microorganisms in the soil stored in an air-dry state for longer periods need certain time to adapt to the changed conditions of soil moisture. The highest denitrifying activity seen in the stored soil (RL No. 724) was accompanied by the highest decrease in the Eh value $(+197 \mathrm{mV})$, compared with the rest of the stored soils at the beginning of incubation. Considering the influence of the length of storage of the soil and type of soils on the aeration status, it was found that the long storage time under dry conditions caused a greater decrease in the Eh value compared with the fresh soils. The average Eh value for the stored soils was $+253 \mathrm{mV}$ and for the fresh ones $+303 \mathrm{mV}$ at the beginning of incubation. This means that the Eh value in the stored soils dropped by $50 \mathrm{mV}$. The biggest difference in Eh between the stored and fresh soils was observed in $\mathrm{HPh}$ No. $633(158 \mathrm{mV})$ while the smallest one in HP No. $633(36 \mathrm{mV})$. The lower Eh value for the stored soils might be due to increa sed availability of $\mathrm{C}$ in these soils. Increased availability of $\mathrm{C}$ caused higher activity of microorganisms, which led to more rapid oxygen consumption and provided better conditions for denitrification. DeAngelis et al. (2010) investigated the acclimation and adaptation of microbial communities to fluctuating environmental conditions. Rapid acclimation to changing conditions suggests the presence of populations with existing physiological capacities for energy generation under a suitable range of redox potential conditions. Soil redox plays a key role in regulating biogeochemical transformations in terrestrial ecosystems (Włodarczyk et al., 2005). The major factors influencing denitrification are oxidized nitrogen compounds $\left(\mathrm{NO}_{3}{ }^{-}\right.$and $\left.\mathrm{N}_{2} \mathrm{O}\right)$, redox potential or $\mathrm{O}_{2}$ availability, easily degradable carbon, temperature, and soil pH (Peterson et al., 2013). Yu et al. (2001) found that the $\mathrm{N}_{2} \mathrm{O}$ emissions were regulated within a narrow redox potential range of +120 to $+250 \mathrm{mV}$ due to the balance of $\mathrm{N}_{2} \mathrm{O}$ production and its further reduction to $\mathrm{N}_{2}$. Therefore, after soil submergence, $\mathrm{N}_{2} \mathrm{O}$ is usually produced 
first; however, it is absorbed in the soil after its redox potential decreases (Włodarczyk et al., 2005). Each microorganism type is adapted to specific Eh conditions and is characterized by its ability to develop within a wider or a narrower Eh-range (Husson, 2013). Generally, much higher $\mathrm{N}_{2} \mathrm{O}$ release was observed from the stored than from fresh soils. Furthermore, the cumulative $\mathrm{N}_{2} \mathrm{O}$ release from the stored soils was correlated with the reduced $\mathrm{NO}_{3}{ }^{-}$and a considerably stronger correlation was found in the case of the fresh soils.

In the present study, there was consumption of released headspace- $\mathrm{N}_{2} \mathrm{O}$, after its maximum cumulative amount, between 1 and 3 day of incubation in some soils. The highest $\mathrm{N}_{2} \mathrm{O}$ consumption for $\mathrm{aD}_{\mathrm{N}_{2} \mathrm{O}}$ was found in $\mathrm{HPh}$ No. 601 $(89.9 \%)$ and for $\mathrm{DC}_{\mathrm{N}_{2} \mathrm{O}}$ in HP No. $633(32.6 \%)$ in the fresh soil. There was only one case of $\mathrm{N}_{2} \mathrm{O}$ consumption in the stored soils (MG No 145 99.2\%). These results indicate that some fresh soils reached maximum release of $\mathrm{N}_{2} \mathrm{O}$ much faster compared with the stored soils under comparable conditions of incubation. The difference is due to the long period of drought that affects $\mathrm{C}_{\text {org }}$ bioavailability and the time required for reviving denitrifiers. Włodarczyk et al. (2005) reported that, under certain conditions, soils are able to consume $\mathrm{N}_{2} \mathrm{O}$. The boundary value of redox potential for the emission of $\mathrm{N}_{2} \mathrm{O}$ was about $+250 \mathrm{mV}$ and about $200 \mathrm{mV}$ for consumption thereof under hypoxic conditions. Pastorelli et al. (2011) found that the influx of $\mathrm{C}$ sources and energy into the oligotrophic soil system is a major driving force in biogeochemical cycles. There are several lines of evidence to support the proposal that severe drought augments dissolved organic carbon (DOC) production and thus controls the observed increases in DOC concentration (Worrall and Burt, 2008). There are some indications that the $\mathrm{N}_{2} \mathrm{O}$-reducing activity of soils is positively correlated with the ratio of available $\mathrm{NO}_{3}{ }^{-}$and available organic $\mathrm{C}$ in soils (Senbayrama et al., 2012).

The $\mathrm{aD}_{\mathrm{N}_{2} \mathrm{O}}$ and $\mathrm{DC}_{\mathrm{N}_{2} \mathrm{O}}$ results for the stored and fresh soils indicated that the low natural $\mathrm{NO}_{3}{ }^{-}$content was one of the most limiting factor in the process of $\mathrm{N}_{2} \mathrm{O}$ release, more than the oxygenation status of the investigated soil because $\mathrm{NO}_{3}{ }^{-}$addition resulted in a marked increase in the release of $\mathrm{N}_{2} \mathrm{O}$ compared with the non-amended soils. This means that $\mathrm{NO}_{3}{ }^{-}$and organic carbon were important factors limiting the denitrification process leading to $\mathrm{N}_{2} \mathrm{O}$ release under the experimental conditions. Rivett et al. (2008) found that the critical limiting factors for denitrifying bacteria were oxygen and electron donor concentration and availability. Variability in other environmental conditions, such as the $\mathrm{NO}_{3}{ }^{-}$concentration, nutrient availability, $\mathrm{pH}$, temperature, presence of toxins, and microbial acclimation appears to be less important, exerting only secondary effects on denitrification rates. In our opinion, there are three critical limiting factors influencing the activity of denitrifying bacteria: concentration and availability of electron donors, anaerobic con- ditions, and $\mathrm{NO}_{3}{ }^{-}$content. In our experiment, $\mathrm{NO}_{3}{ }^{-}$(natural and added) very clearly affected $\mathrm{N}_{2} \mathrm{O}$ release and depended on the length of storage of soils and type of soils. The studied soils have a very diverse ability to reduce $\mathrm{NO}_{3}{ }^{-}$. The $\mathrm{NO}_{3}{ }^{-}$ reducing was the highest in MG No. 145 (98.1 and 98.1\%) for the stored and fresh soils, respectively, and the lowest in HP No. 633 (31.1 and 49.0\%) for the stored and fresh soils, respectively. Comparing the effect of the length of the storage of the soils on $\mathrm{NO}_{3}{ }^{-}$-reducing activity of soils, it was found that long storage in the case of two soils (EC No. 553 and $\mathrm{HPh}$ No. 601) slightly affected the increase in the NO3--reducing activity. In three soils (HP No. 633, RL No. 724 and DF No. 941), this activity significantly decreased, which might be connected with their individual biogeochemistry characteristics. In the case of MG (No. 145), the reducing activity was comparable. Generally, it can be concluded that long storage slightly decreased $\mathrm{NO}_{3}{ }^{-}$reduction activity. Dodla et al. (2008) found that the capacity of wetland to remove $\mathrm{NO}_{3}{ }^{-}$through denitrification was controlled by its physicochemical and biological characteristics.

With regards to the effects of the length of the soil storage on $\mathrm{NO}_{3}{ }^{-}$-reduction activity to $\mathrm{N}_{2} \mathrm{O}$ formation, it was found that long storage of soils increased $\mathrm{NO}_{3}{ }^{-}$reduction activity to $\mathrm{N}_{2} \mathrm{O}$ formation. We can expect that soils subjected to prolonged drought will produce more $\mathrm{N}_{2} \mathrm{O}$ than soils exposed to dry conditions for shorter times.

The cumulative $\mathrm{N}_{2} \mathrm{O}$ release from the stored soils was correlated with the reduced $\mathrm{NO}_{3}{ }^{-}$and a substantially stronger correlation was found in the case of the fresh soils. There was also a close correlation between the cumulative $\mathrm{N}_{2} \mathrm{O}$ released and $\mathrm{C}_{\text {org }}$ content for the stored and fresh soils enriched with $\mathrm{NO}_{3}^{-}\left(\mathrm{DC}_{\mathrm{N}_{2} \mathrm{O}}\right)$. There was no correlation between the cumulative $\mathrm{N}_{2} \mathrm{O}$ released and $\mathrm{CO}_{2}$ released for the stored and fresh soils for both $\mathrm{aD}_{\mathrm{N}_{2} \mathrm{O}}$ and $\mathrm{DC}_{\mathrm{N}_{2} \mathrm{O}}$. Under conditions of hypoxia, $\mathrm{CO}_{2}$ came from both the process of aerobic respiration and anaerobic $\left(\mathrm{NO}_{3}{ }^{-}\right)$respiration. The activity of both processes may depend inter alia on the oxygenation status of the soil and the availability of oxygen, which is depended on the intensity of both respiration processes, especially in short-term incubation (7 days). Thus, there was no clear relationship between $\mathrm{N}_{2} \mathrm{O}$ and $\mathrm{CO}_{2}$ release. Furthermore, soil microorganisms maintain their microbiological activity for many years from the time of sampling of agricultural soils. This feature in bacterial strains indicates some capacity for memory (Włodarczyk, 2000). Harrison-Kirk et al. (2013) have reported that moisture stress history can affect the size of the $\mathrm{CO}_{2}$ flush following rewetting of dry soil.

The SOM content and texture are important factors affecting carbon $(\mathrm{C})$ and nitrogen $(\mathrm{N})$ mineralization under constant soil moisture but their effects on organic matter mineralization and associated biogenic gas like $\mathrm{CO}_{2}$ and $\mathrm{N}_{2} \mathrm{O}$ production during dry/wet cycles is poorly studied (Harrison-Kirk et al., 2013). The tested soil showed a highly 
differentiated respiration activity measured as the amount of $\mathrm{CO}_{2}$ released depending on the length of storage and type of soils under flooding after drought. While comparing the amount of $\mathrm{CO}_{2}$ released from the stored and fresh soils, it can be assumed that respiration activity was comparable in three soils (EC No. 553, HPh. No. 601, and DF No. 941). In one soil (RL) respiration activity was about half lower in the stored soils while, in two soils (MG and HP), respiration was significantly higher in the stored soils than in the fresh ones. Probably during the prolonged drought in these soils, there was a steady decomposition of organic matter (OM) and accumulation of easily available OM due to the minimum soil moisture during storage and, consequently, deceleration of vital functions of microorganisms. Wetting of dry soil typically results in a flush of $\mathrm{C}$ and $\mathrm{N}$ mineralization, with elevated rates of $\mathrm{CO}_{2}$ production persisting for up to 2 weeks following wetting (Beare et al., 2009). Worrall and Burt (2008) studied the effect of severe drought on the biogeochemistry of dissolved organic carbon (DOC) production. This study derives five different drought severity indices and compares these to the observed increase in DOC over a 4-year period after each severe drought. Xiang et al. (2008) found that drying and rewetting led to a cascade of responses (soluble $\mathrm{C}$ release, biomass growth, and enhanced activity) that mobilized and metabolized otherwise unavailable soil carbon, particularly in subsurface soils.

The $\mathrm{CO}_{2}$ release was the highest in MG No. 145 (529 mg $\left.\mathrm{CO}_{2}-\mathrm{C} \mathrm{kg}^{-1}\right)$ for the stored soils and it was 5 times greater than for the same fresh soil (103.8 $\mathrm{mg} \mathrm{CO}_{2}-\mathrm{C} \mathrm{kg}^{-1}$ ) under control-flooded conditions. It has long been recognized that rewetting a dry soil causes a pulse of respiration - the 'Birch Effect' (Birch, 1958). More than twice as much $\mathrm{CO}_{2}-\mathrm{C}$ was evolved from the long-term stored soils than from the freshly sampled ones (De Nobili et al., 2006). The lowest $\mathrm{CO}_{2}$ release was found in MP No. $633\left(40.5 \mathrm{mg} \mathrm{CO}_{2}-\mathrm{C} \mathrm{kg}^{-1}\right)$ for the stored soils. The highest $\mathrm{CO}_{2}$ release was observed in DF No. 941 (187.6 $\left.\mathrm{mg} \mathrm{CO}_{2}-\mathrm{C} \mathrm{kg}^{-1}\right)$ and the lowest one in HP No. 633 (50.8 $\mathrm{mg} \mathrm{CO}_{2}-\mathrm{C} \mathrm{kg}^{-1}$ ) for the fresh soils. HarrisonKirk et al. (2013) studied $\mathrm{CO}_{2}$ production during sequential dry/wet cycles at laboratory incubation. Following rewetting, the very dry and moderately dry soils produced a shortterm $\mathrm{C}$ mineralization flush that was, on average, 30\% and $15 \%$ greater, respectively, than in wet (field capacity) soils. On average, the total $\mathrm{CO}_{2}$ release from the control soils was slightly higher (199.5 and $132.4 \mathrm{mg} \mathrm{CO}_{2}-\mathrm{C} \mathrm{kg}^{-1}$ in the stored and fresh soils, respectively) compared with the $\mathrm{NO}_{3}{ }^{-}$ enriched soils (197.9 and $129.2 \mathrm{mg} \mathrm{CO}_{2}-\mathrm{C} \mathrm{kg}^{-1}$ in the stored and fresh soils, respectively).

A differentiated rate of respiration activity of the soils, depending on the length of storage and the type of soil, should be noted. A substantially higher rate of $\mathrm{CO}_{2}$ release at the beginning of incubation was shown in the fresh soils. In most of the fresh soils, the highest rate of $\mathrm{CO}_{2}$ release was reported after the first day of incubation $(\mathrm{EC}, \mathrm{HPh}, \mathrm{HP}$, and $\mathrm{RL}$ ); the other soils (MG and DF) needed three days to reach the highest rate of $\mathrm{CO}_{2}$ release, while among the stored soils, only two soils (EC and HPh) needed one day to be fully active. The other soils needed three or seven days to adapt to the new conditions of soil moisture. This demonstrates that microorganisms (denitrifying bacteria and other microorganisms) in fresh soils are characterized by a higher adaptive ability to changes in the availability of $\mathrm{C}$ and $\mathrm{O}_{2}$ in the headspace and soil suspension and the faster change in the type of respiration from aerobic to $\mathrm{NO}_{3}{ }^{-}$respiration. In turn, in the soil stored in an air-dry state much longer, they need more time to adapt to the changed aeration status of the stored soils. Similarly, in the incubation experiments aimed at analysis the methanogenic potential of long stored soils, the methanogenesis started with time lag (Brzezińska et al., 2014).

Comparing the $\mathrm{C}_{\text {org }}$ content of the stored and fresh soils, we can recognise falling trends due to the storage of the soil. The average $\mathrm{C}_{\text {org }}$ content for the investigated soils was 1.78 and 2.38 for the stored and fresh soils, respectively.

Generally, the cumulative $\mathrm{CO}_{2}$ release from the stored soils was correlated with the $\mathrm{C}_{\text {org }}$, but there was no correlation in the case of the fresh soils.

\section{CONCLUSIONS}

1. The investigations answered two main questions about the influence of long-term storage on the actual denitrification leading to $\mathrm{N}_{2} \mathrm{O}$ formation with a natural content of $\mathrm{N}$ in the soil and $\mathrm{C}$ after flooding and on the denitrification capacity leading to $\mathrm{N}_{2} \mathrm{O}$ formation when the process is not limited by deficiency of $\mathrm{NO}_{3}$ after flooding from the standpoint of environmental protection.

2. The investigated soils showed very low actual denitrification to $\mathrm{N}_{2} \mathrm{O}$ irrespectively of the length of storage under flooding. There was no $\mathrm{N}_{2} \mathrm{O}$ release from the stored soils but the fresh soils had very low actual denitrification to $\mathrm{N}_{2} \mathrm{O}$.

3. The low native content of $\mathrm{NO}_{3}{ }^{-}$was a factor clearly limiting the denitrification process, in particular to the form of $\mathrm{N}_{2} \mathrm{O}$.

4. The amount of $\mathrm{N}_{2} \mathrm{O}$ released (denitrification capacity to $\mathrm{N}_{2} \mathrm{O}$ ) significantly increased after $\mathrm{NO}_{3}{ }^{-}$addition and depended on the length of soil storage and type of soils, and it was much higher in the stored soils. The $\mathrm{N}_{2} \mathrm{O}$ release was highest in Rendzic Leptosols and Distric Fluvisols for the stored and fresh soils. The lowest $\mathrm{N}_{2} \mathrm{O}$ release was found in Haplic Phaeozems for the stored soil and in Haplic Podzols for the fresh soil. Some soils showed the capability of $\mathrm{N}_{2} \mathrm{O}$ consumption. The cumulative $\mathrm{N}_{2} \mathrm{O}$ release from the stored soils was correlated with the reduced $\mathrm{NO}_{3}{ }^{-}$and a remarkably stronger correlation was found in the case of the fresh soils. There was also a close correlation between the cumulative $\mathrm{N}_{2} \mathrm{O}$ release and organic $\mathrm{C}$ content for the stored and fresh soils enriched with $\mathrm{NO}_{3}{ }^{-}$(denitrification capacity to $\mathrm{N}_{2} \mathrm{O}$ ).

6 . The studied soils were characterized by a very diverse ability to reduce $\mathrm{NO}_{3}{ }^{-}$. The $\mathrm{NO}_{3}{ }^{-}$reduction was the highest in Mollic Gleysols for both the stored and fresh soils and the 
lowest one was reported for Haplic Podzols for the stored and fresh soils. The long storage slightly decreased $\mathrm{NO}_{3}{ }^{-}$ reduction activity and $\mathrm{N}_{2} \mathrm{O}$ formation.

7. The tested soil showed a very variable respiration activity measured as the amount of $\mathrm{CO}_{2}$ released during incubation depending on the length of storage and type of soils under flooding after drought. The respiration activity of soils was comparable in three soils (Eutric Cambisols, Haplic Phaeozems, and Distric Fluvisols) in the stored and fresh soils. In two soils (Mollic Gleysols and Haplic Podzols), respiration was significantly higher in the stored soils than in the fresh ones, while in one soil (Rendzic Leptosols) the respiration activity was about half lower in the stored soils. The $\mathrm{CO}_{2}$ release was the highest in Mollic Gleysols for the stored soil and 5 times greater than in the same fresh soil. The lowest $\mathrm{CO}_{2}$ release was found in Haplic Phaeozems for the stored soil. The highest $\mathrm{CO}_{2}$ release for the fresh soils was observed in Distric Fluvisols and the lowest one in Haplic Podzols.

8. Comparing the organic $\mathrm{C}$ content in stored and fresh soils, we can recognize falling trends due to the storage of the soils. The cumulative $\mathrm{CO}_{2}$ release from the stored soils was correlated with the organic $\mathrm{C}$, but there was no correlation in the case of the fresh soils.

9. The long-time soil storage under air-dry conditions caused a greater decrease in the Eh value compared with the fresh but air-dry soils.

\section{REFERENCES}

Almasri M.N. and Kaluarachchi J.J., 2004. Assessment and management of long-term nitrate pollution of ground water in agriculture-dominated watersheds. J. Hydrol., 295, $225-245$.

Beare M.H., Gregorich E.G., and St-Georges P., 2009. Compaction effects on $\mathrm{CO}_{2}$ and $\mathrm{N}_{2} \mathrm{O}$ production during drying and rewetting of soil. Soil Biol. Biochem., 41, 611-621.

Bieganowski A., Ryżak M., and Witkowska-Walczak B., 2010. Determination of soil aggregate disintegration dynamic Rusing laser diffraction. Clay Minerals, 45, 23-34.

Bieganowski A., Witkowska-Walczak B., Gliński J., Sokołowska Z., Sławiński C., Brzezińska M., and Włodarczyk T., 2013. Database of Polish arable mineral soils: a review. Int. Agrophys., 27, 335-350.

Birch H.F., 1958. The effect of soil drying on humus decomposition and nitrogen. Plant Soil, 10, 9-31.

Brzezińska M., Urbanek E., Szarlip P., Włodarczyk T., Bułak P, Walkiewicz A., and Rafalski P., 2014. Methanogenic potential of archived soils. Carphatian J. Earth Environ. Sci., 9, 79-90.

Burford J.R. and Bremner J.M., 1975. Relationships between the denitrification capacities of soils and total water soluble and readily decomposable soil organic matter. Soil Biol. Biochem., 7, 389-394.

DeAngelis K.M., Silver W.L., Thompson A.W., and Firestone M.K., 2010. Microbial communities acclimate to recurring changes in soil redox potential status. Environ. Microbiol., 12, 3137-3149.
De Nobili M., Contin M., and Brookes P.C., 2006. Microbial biomass dynamics in recently air-dried and rewetted soils compared to others stored air-dry for up to 103 years. Soil Biol. Biochem., 38, 2871-2881.

Dodla S.K., Wang J.J., DeLaune R.D., and Cook R.L., 2008 Denitrification potential and its relation to organic carbon quality in three coastal wetland soils. Science of the Total Environment, 407, 471-480.

Gliński J. and Stępniewski W., 1985. Soil Aeration and its Role for Plants. CRC Press, Boca Raton, FL, USA.

Hanke A. and Strous M., 2010. Climate, fertilization, and the nitrogen cycle. J. Cosmology, 8, 1838-1845.

Harrison-Kirk T., Beare M.H., Meenken E.D., and Condron L.M., 2013. Soil organic matter and texture affect responses to dry/wet cycles: Effects on carbon dioxide and nitrous oxide emissions. Soil Biol. Biochem., 57, 43-55.

Hayatsu M., Tago K., and Saito M., 2008. Various players in the nitrogen cycle: diversity and functions of the microorganisms involved in nitrification and denitrification. Soil Scie. Plant Nutr., 54, 33-45.

Husson O., 2013. Redox potential (Eh) and $\mathrm{pH}$ as drivers of soil/plant/microorganism systems: a transdisciplinary overview pointing to integrative opportunities for agronomy. Plant Soil, 362, 389-417.

IPCC, 2007. Summary for policy makers. Intergovernmental Panel on Climate Change (IPCC). Climate Change 2007: The physical science basis. Contribution of working group I to the 4th Assessment Rep. (AR4) of Intergovernmental panel on climate change. Cambridge University Press, UK.

Kraft B., Strous M., and Tegetmeyer H.E., 2011. Microbial nitrate respiration - Genes, enzymes and environmental distribution. J. Biotechnol., 155, 104-117.

Kroze C., Mossier A., and Bouwman L., 1999. Closing the global $\mathrm{N}_{2} \mathrm{O}$ budget: a retrospective analysis. Global Biogeochem. Cycle., 13, 1-8.

Oliveira T.S.., Costa L.M.., and Schaefer C.E., 2005. Waterdispersible clay after wetting and drying cycles in four Brazilian oxisols. Soil Till. Res., 83, 260-269.

Pastorelli R., Landi S., Trabelsi D., Piccolo R., Mengoni A., Bazzicalupo M., and Pagliai M., 2011. Effects of soil management on structure and activity of denitrifying bacterial communities. Applied Soil Ecol., 49, 46-58.

Peterson M.E., Curtin D., Thomas S., Clough T.J., and Meenken E.D., 2013. Denitrification in vadose zone material amended with dissolved organic matter from topsoil and subsoil. Soil Biol. Biochem., 61, 96-104.

Ravishankara A.R., Daniel J.S., and Portmann R.W., 2009. Nitrous Oxide $\left(\mathrm{N}_{2} \mathrm{O}\right)$ : the dominant ozone-depleting substance emitted in the 21st century. Science, 326, 123-125.

Rivett M.O., Buss S.R., Morgan P., Smith J.W.N., and Bemment Ch.D., 2008. Nitrate attenuation in groundwater: A review of bio-geochemical controlling processes. Water Res., 42, 4215-4232.

Ryżak M. and Bieganowski A., 2011. Methodological aspects of determining soil particle-size distribution using the laserdiffraction method. J. Plant Nutr. Soil Sci., 174, 624-633.

Senbayram M., Chen R., Budai A., Bakken L., and Dittert K., 2012. $\mathrm{N}_{2} \mathrm{O}$ emission and the $\mathrm{N}_{2} \mathrm{O} /\left(\mathrm{N}_{2} \mathrm{O}+\mathrm{N}_{2}\right)$ product ratio of denitrification as controlled by available carbon substrates and nitrate concentrations. Agriculture, Ecosystems Environ., 147, 4-12. 
Sochan A., Bieganowski A., Ryżak M., Dobrowolski R., and Bartmiński P., 2012. Comparison of soil texture determined by two dispersion units of Mastersizer 2000. Int. Agrophys., 26, 99-102.

Šimek M., Elhottová D., Klimeš F., and Hopkins D.W., 2004. Emissions of $\mathrm{N}_{2} \mathrm{O}$ and $\mathrm{CO}_{2}$ denitrification measurements and soil properties in red clover and ryegrass stands. Soil Biol. Biochem., 36, 9-21.

Włodarczyk T., 2000. Some of aspects of dehydrogenase activity in soils. Int. Agrophysics, 14, 341-354.

Włodarczyk T., Stępniewski W., and Brzezińska M., 2005. Nitrous oxide production and consumption in Calcaric Regosols as related to soil redox and texture. Int. Agrophysics, 19, 263-271.

Włodarczyk T., Stępniewski W., Brzezińska M., and Majewska U., 2011. Various textured soil as nitrous oxide emitter and consumer. Int. Agrophys., 25, 287-297.

Włodarczyk T., Stępniewski W., Brzezińska M., and Stępniewska Z., 2004. Nitrate stability in loess soils under anaerobic conditions - laboratory studies. J. Plant Nutr. Soil Sci., 167, 693-700.
Worrall F. and Burt T.P., 2008. The effect of severe drought on the dissolved organic carbon (DOC) concentration and flux from British rivers. Journal of Hydrology, 361, 262-274.

Wu J. and Brookes P.C., 2005. The proportional mineralisation of microbial biomass and organic matter caused by airdrying and rewetting of a grassland soil. Soil Biol. Biochem., 37, 507-515.

Xiang S.R., Doyle A., Holden P.A., and Schimel J.P., 2008. Drying and rewetting effects on $\mathrm{C}$ and $\mathrm{N}$ mineralization and microbial activity in surface and subsurface California grassland soils. Soil Biol. Biochem., 40, 2281-2289.

Yu K., Faulkner S.P., and Patrick Jr.W.H., 2006. Redox potential characterization and soil greenhouse gas concentration across a hydrological gradient in a Gulf coast forest. Chemosphere, 62, 905-914.

Yu K.W., Wang Z.P., Vermoesen A., Patrick Jr W.H., and Van Cleemput O., 2001. Nitrous oxide and methane emissions from different soil suspensions: effect of soil redox status. Biol. Fertility Soils, 34, 25-30.

Zhang J., Cai Z., and Zhu T., 2011. $\mathrm{N}_{2} \mathrm{O}$ production pathways in the subtropical acid forest soils in China. Environ. Res., 111, 643-649. 